\title{
Metabolic Syndrome and HIV Infection Abhijit Swami
}

\author{
Associate Professor of Medicine, Silchar \\ Medical College, Assam, India
}

Corresponding author: Nguefack Félicitée

\section{drabhijitswami@gmail.com}

\begin{abstract}
Associate Professor of Medicine, Silchar Medical College, Silchar Assam 788015, India,
\end{abstract}

Tel: 09435074466

Citation: Swami A, Metabolic Syndrome and HIV Infection. J HIV Retrovirus. 2016, 2:1.

2012 have shown a prevalence rate of $18.3 \%$ among those aged 20 to 39 years which increased to $46.7 \%$ among those aged 60 years or older with a higher incidence noted among women [2-9]. Even in the developing countries of South Asia which incidentally has high incidence of Type 2 DM, MeTS has shown an increasing prevalence among all age groups with an additional component of being a more urban rather than rural phenomenon [10].

\section{Pathogenesis of Metabolic Syndrome}

Metabolic syndrome is now thought to be the result of a complex interplay between environmental and genetic factors. The initial event is believed to be development of abdominal obesity, which is now known to cause insulin resistance. Adipose tissue in the abdomen is known to be metabolically active and produce a variety of cytokines - adipocytokines which includes glycerol, Free Fatty Acids (FFA), proinflammatory mediators (Tumor Necrosis Factor Alpha (TNF $\alpha$ ) and Interleukin-6 (IL-6)), Plasminogen Activator Inhibitor-1 (PAI-1), and C-Reactive Protein (CRP) [11]. Increased production of free fatty acids, inflammatory cytokines, and adipokines and mitochondrial dysfunction contribute to impaired insulin signaling, decreased skeletal muscle glucose uptake, increased hepatic gluconeogenesis, and $\beta$ cell dysfunction, leading to hyperglycemia. In addition, insulin resistance leads to the development of hypertension by impairing vasodilation induced by nitric oxide.

Though obesity has been linked to environmental and genetic factors, several recent studies have opened a new dimension into our understanding of obesity and metabolic syndrome. Chronic low grade inflammation of multiple etiologies- both infectious 
and non-infectious has been linked to development of obesity in susceptible individuals which again is further compounded by using of disease specific medications.

Of particular interest have been the recent observations that chronic infectious diseases like HIV and chronic hepatitis B and C are associated with MeTS. High blood levels of pro-inflammatory cytokines like CRP have been found in these conditions indicating enhanced inflammation. Chronic Hepatitis B and C patients have high level of several coronary disease markers though these diseases have not been conclusively linked to coronary artery disease $[12,13]$. However, the infectious disease which has been conclusively linked with MeTS for more than two decades has been HIV infection even if the patient has responded to antiretroviral therapy. The high prevalence of MeTS in HIV infection has added entirely new dimensions in the pathogenesis of MeTS.

The initial description of MeTS was made in HIV patients few years after initiation of protease inhibitor chiefly ritonavir plus saquinavir combination based antiretroviral therapy. The unquestionable success of ART has lead to a wider availability of the drugs around the globe thereby bringing to notice an unanticipated aspect of drug therapy of HIV. Though the actual numbers of MetS in HIV populations are still debatable, reported prevalence for MetS in the HIV population can be regarded as high, ranging from $11.2 \%$ up to $45.4 \%$ [14].

Since its initial description about three decades back, our understanding of HIV has increased exponentially. With effective therapy, the infection has been converted from a disease with profound immune suppression and often terminal, fatal opportunistic infections to a disease associated with disordered lipid metabolism, dysglycemia and high blood pressure with increased proinflammatory cytokines. And as HIV patients live longer, this aspect of HIV infection is now an important global health concern.

The pathogenesis of MeTS is not completely understood. The metabolic changes in HIV infections begin early in the course of infection. Due to selective targeting of the immune system by the virus and the consequent progressive deterioration of the immune system, the individual becomes susceptible to multiple opportunistic infections and some neoplasm. Targeting of the immune system by the virus causes profound disruption of the cytokine network from the earliest stages of HIV infection. Cytokines like hS-CRP, tumor necrosis factor, IL-6, IL-1ß, urokinase plasminogen activator receptor (suPAR) and IL-6 are increased in the initial stages of HIV infection and these not only contributes to viral replication but also initiates the earliest changes leading to development of metabolic syndrome in future [15]. Some genes responsible for suppressing inflammation like tyrosine kinase RON are downregulated in HIV infection leading to continuing inflammatory response and increased HIV transcription [16]. Even after institution of HAART (Highly Active Antiretroviral Therapy) with HIV levels below detectable range, the blood levels of these cytokines remain elevated. In the SMART trial, participants bearing $\leq 400$ copies/mL of HIV RNA also had elevated hsCRP and IL-6 levels in $38 \%$ and $60 \%$, respectively, in comparison to normal individuals form cohorts for cardiovascular outcomes [17].

The earliest changes in the treatment naïve HIV patients are probably dyslipidemia with plummeting of HDL levels. As the disease progresses, LDL-C decreases followed by an increase in triglycerides, apolipoprotein levels and VLDL in the advance course of the disease. Hypertriglyceridemia may be due to decreased clearance of triglycerides and increased production of VLDL [18].

Once the patients are initiated on HAART, the impact on the components of MeTS is more pronounced. Some of the initial changes found in the early stages of HIV infection get exacerbated with addition of more components. These changes depend on the medications on the HAART regime. Hypertriglyceridemia in general worsens with Ritonavir based PI regime with an increase up to $83 \%$ in one study and could be due to effect of Ritonavir on inhibitory effect on degradation of apolipoprotein B [19].

Insulin resistance can occur in HIV patients on therapy, but probably the mechanism is different from the general population. Multiple antiretroviral drugs - zidovudine, lamivudine, stavudine, efavirenz and most of the protease inhibitors have been found to have influence on glucose metabolism though by different mechanisms some of which are still not well understood. Studies have shown that PIs selectively inhibit glucose transport in adipocytes without affecting early insulin-signaling events or translocation of intracellular GLUT4 transporters to the cell surface [20].

The resultant effect of HIV infection with or without therapy lead to a state of immune dysfunction with profound influence on lipid metabolism, body habitus and vascular architecture leading to a prothrombotic state thereby enhancing the risk of cardiovascular diseases manifold (Table 1 and Figure 1) [21].

\section{Fat Distribution and Metabolic Syndrome}

The most visible effect of metabolic syndrome in HIV patients is the development of lipodystrophy which includes facial lipoatrophy (fat loss), increased upper trunk fat (buffalo hump), lipoatrophy of the arms and legs, and abdominal obesity. HIV patients also experience increase prevalence of ectopic fat distribution in liver and muscles [22]. This is not seen in treatment naïve HIV patients, but more common once HAART is initiated with PI based regimes and also with stavudine, which mercifully is now rarely used. Central obesity as a consequence of lipodystrophy is a component of MeTS. Also these patients have abdominal subcutaneous lipoatrophy more pronounced in the abdomen with consequent loss of hip circumference and spuriously elevated waist hip ratio. This makes inclusion of waist hip ratio an unreliable component in the diagnosis of HIV induced metabolic syndrome (Table 2).

\section{Hypertension}

The link between HIV infection and development of hypertension is at best tenuous. Epidemiological studies have not found an increased incidence of hypertension in treatment naïve HIV patients [23]. However, use of effective antiretroviral therapy 
Table 1: Diagnostic criteria for the clinical diagnosis of the MetS [2-8].

\begin{tabular}{|c|c|c|c|c|c|}
\hline Clinical measures & WHO (1998) & EGIR (1999) & ATPIII (2001) & AACE (2003) & IDF (2005) \\
\hline Insulin resistance & $\begin{array}{l}\text { IGT, IFG, T2DM, } \\
\text { or lowered insulin } \\
\text { Sensitivity } \\
\text { plus any } 2 \text { of the } \\
\text { following }\end{array}$ & $\begin{array}{l}\text { Plasma insulin }>75 \text { th } \\
\text { percentile } \\
\text { plus any } 2 \text { of the } \\
\text { following }\end{array}$ & $\begin{array}{l}\text { None, but any } 3 \\
\text { of the following } \\
5 \text { features }\end{array}$ & $\begin{array}{l}\text { IGT or IFG } \\
\text { plus any of the } \\
\text { following based on } \\
\text { the clinical judgment }\end{array}$ & None \\
\hline Body weight & $\begin{array}{l}\text { Men: waist-to-hip } \\
\text { ratio }>0.90 \text {; } \\
\text { women: waist-to-hip } \\
\text { ratio }>0.85 \text { and/or } \\
\mathrm{BMI}>30 \mathrm{~kg} / \mathrm{m}^{2}\end{array}$ & $\begin{array}{l}W C \geq 94 \mathrm{~cm} \text { in men } \\
\text { or } \geq 80 \mathrm{~cm} \text { in women }\end{array}$ & $\begin{array}{l}W C \geq 102 \mathrm{~cm} \text { in } \\
\text { men or } \geq 88 \mathrm{~cm} \text { in } \\
\text { women }\end{array}$ & $\mathrm{BMI} \geq 25 \mathrm{~kg} / \mathrm{m}^{2}$ & $\begin{array}{l}\text { Increased WC (population specific) } \\
\text { plus any } 2 \text { of the following }\end{array}$ \\
\hline Lipids & $\begin{array}{l}\text { TGs } \geq 150 \mathrm{mg} / \mathrm{dL} \\
\text { and/or } \mathrm{HDL}-\mathrm{C} \\
<35 \mathrm{mg} / \mathrm{dL} \text { in men } \\
\text { or }<39 \mathrm{mg} / \mathrm{dL} \text { in } \\
\text { women }\end{array}$ & $\begin{array}{l}\text { TGs } \geq 150 \mathrm{mg} / \mathrm{dL} \\
\text { and/or HDL-C } \\
<39 \mathrm{mg} / \mathrm{dL} \text { in men or } \\
\text { women }\end{array}$ & $\begin{array}{l}\mathrm{TGs} \geq 150 \mathrm{mg} / \mathrm{dL} \\
\mathrm{HDL}-\mathrm{C}<40 \mathrm{mg} / \mathrm{dL} \text { in } \\
\text { men or }<50 \mathrm{mg} / \mathrm{dL} \\
\text { in women }\end{array}$ & $\begin{array}{l}\mathrm{TGs} \geq 150 \mathrm{mg} / \mathrm{dL} \text { and } \\
\mathrm{HDL}-\mathrm{C}<40 \mathrm{mg} / \mathrm{dL} \text { in } \\
\text { men or }<50 \mathrm{mg} / \mathrm{dL} \text { in } \\
\text { women }\end{array}$ & $\begin{array}{l}\text { TGs } \geq 150 \mathrm{mg} / \mathrm{dL} \text { or on TGs } \mathrm{Rx} . \\
\mathrm{HDL}-\mathrm{C}<40 \mathrm{mg} / \mathrm{dL} \text { in men or }<50 \mathrm{mg} / \\
\mathrm{dL} \text { in women or on HDL-C Rx }\end{array}$ \\
\hline Blood pressure & $\geq 140 / 90 \mathrm{~mm} \mathrm{Hg}$ & $\begin{array}{l}\geq 140 / 90 \mathrm{~mm} \mathrm{Hg} \text { or } \\
\text { on hypertension } \mathrm{Rx}\end{array}$ & $\geq 130 / 85 \mathrm{~mm} \mathrm{Hg}$ & $\geq 130 / 85 \mathrm{~mm} \mathrm{Hg}$ & $\begin{array}{l}\geq 130 \mathrm{~mm} \mathrm{Hg} \text { systolic or } \geq 85 \mathrm{~mm} \mathrm{Hg} \\
\text { diastolic or on hypertension } \mathrm{Rx}\end{array}$ \\
\hline Glucose & IGT, IFG, or T2DM & $\begin{array}{l}\text { IGT or IFG (but not } \\
\text { diabetes) }\end{array}$ & $\begin{array}{l}>110 \mathrm{mg} / \mathrm{dL} \\
\text { (includes diabetes) }\end{array}$ & $\begin{array}{l}\text { IGT or IFG (but not } \\
\text { diabetes) }\end{array}$ & $\geq 100 \mathrm{mg} / \mathrm{dL}$ (includes diabetes) $^{\mathrm{b}}$ \\
\hline
\end{tabular}

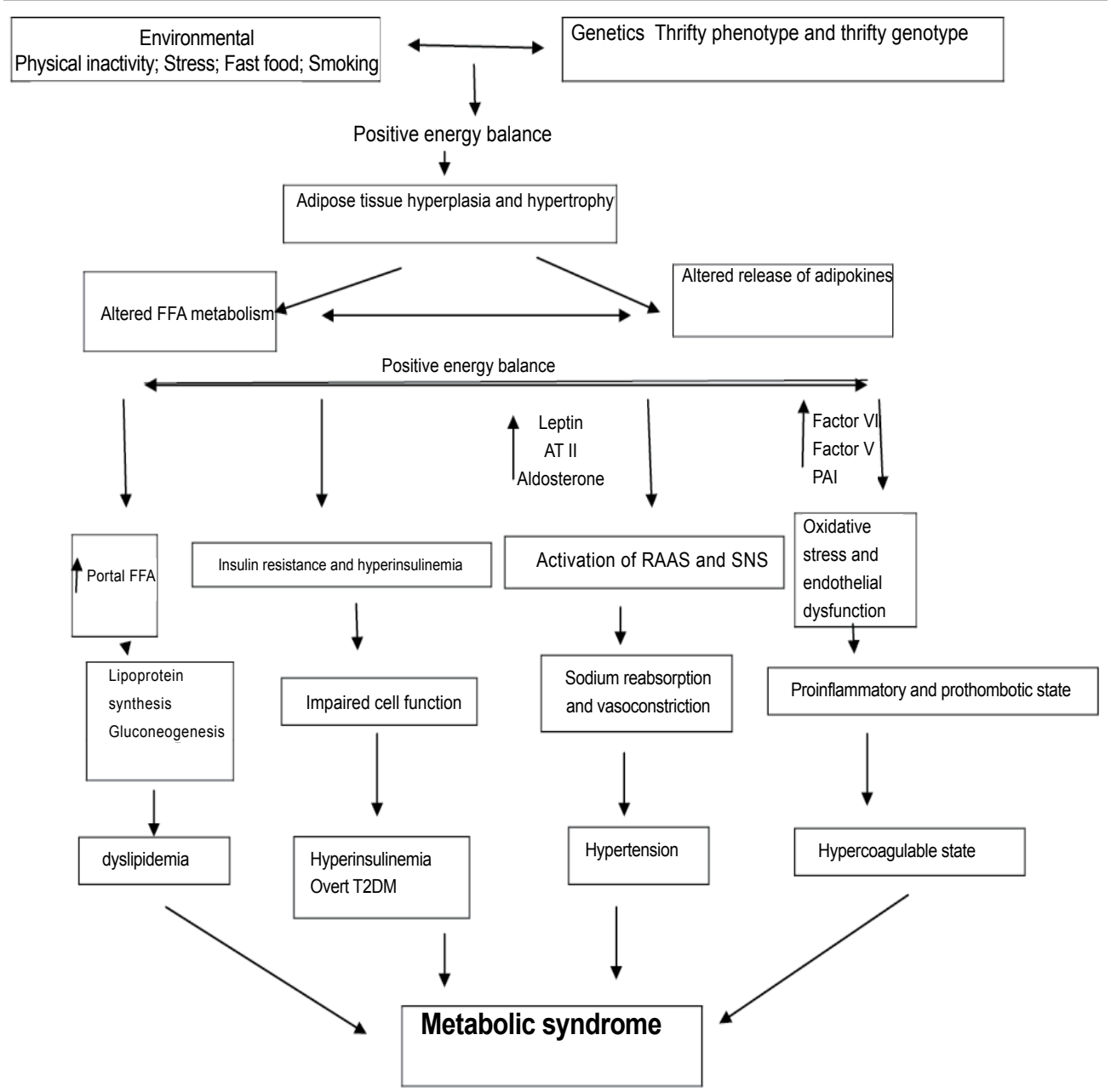

Figure 1 Schematic presentation of MetS (FFA: Free Fatty Acid, ATII: Angiotensin II, PAI-1: Plasminogen Activator Inhibitor-1, RAAS: Renin Angiotensin Aldosterone System, SNS: Sympathetic Nervous System) [2]. 
Table 2: Harmonized definition [3].

\begin{tabular}{|c|c|}
\hline Measure & Categorical Cut Points \\
\hline Elevated waist circumference* & $\begin{array}{l}\text { Population- and country- } \\
\text { specific definitions }\end{array}$ \\
\hline $\begin{array}{l}\text { Elevated triglycerides (drug treatment } \\
\text { for elevated triglycerides is an alternate } \\
\text { indicatort) }\end{array}$ & $\geq 150 \mathrm{mg} / \mathrm{dL}(1.7 \mathrm{mmol} / \mathrm{L})$ \\
\hline $\begin{array}{l}\text { Reduced } \mathrm{HDL}-\mathrm{C} \text { (drug treatment for } \\
\text { reduced } \mathrm{HDL}-\mathrm{C} \text { is an alternate indicator }{ }^{+} \text {) }\end{array}$ & $\begin{array}{l}<40 \mathrm{mg} / \mathrm{dL}(1.0 \mathrm{mmol} / \mathrm{L}) \\
\text { in males; }<50 \mathrm{mg} / \mathrm{dL}(1.3 \\
\mathrm{mmol} / \mathrm{L}) \text { in females }\end{array}$ \\
\hline $\begin{array}{l}\text { Elevated blood pressure (antihypertensive } \\
\text { drug treatment in a patient with a history } \\
\text { of hypertension is an alternate indicator) }\end{array}$ & $\begin{array}{l}\text { Systolic } \geq 130 \text { and/or } \\
\text { diastolic } \geq 85 \mathrm{~mm} \mathrm{Hg}\end{array}$ \\
\hline $\begin{array}{l}\text { Elevated fasting glucose } \neq \text { (drug treatment } \\
\text { of elevated glucose is an alternate } \\
\text { indicator) }\end{array}$ & $\geq 100 \mathrm{mg} / \mathrm{dL}$ \\
\hline $\begin{array}{l}\text { Presence of any } 3 \text { of } 5 \text { risk factors constitut } \\
\text { syndrome }\end{array}$ & \\
\hline
\end{tabular}

has been linked to development of hypertension though some reports have implicated protease inhibitors as the cause [24]. Increase in BMI after effective antiretroviral therapy has been postulated as the cause of hypertension.

\section{Therapy for Metabolic syndrome in HIV}

Advances in therapeutics have converted HIV from an invariably fatal disease to a chronic disease where a patient has less chance of succumbing to opportunistic infections, but at the cost of development of metabolic syndrome. The disease itself along with the drugs used to treat the disease are the main causes with smoking and limited physical activity contributing to the process.

Cessation of smoking is the single most important and the easiest therapy MeTS in HIV patients without any side effects. HIV infected patients are more likely to be smokers and cessation of smoking was associated a reduction of cardiovascular diseases in the DAD study [25]. Management of dyslipidemia should include non-drug measures like dietary modifications to attain ideal body weight and increased physical activity depending upon the general condition of the patient. Routine aerobic activity and muscle conditioning exercise improved trunk adiposity and lipid parameters in HIV infected patients [26]. Dietary modifications at diagnosis even before initiation of Anti-retroviral therapy prevented development of MeTS [27]. In the management of dyslipidemia, lipid lowering drugs are indicated but, drug-drug interaction should be considered when combined with PI based HAART. Older statins like lovastatin and simvastatin are better avoided while newer ones like atorvastatin and rosuvastation are to be used with caution. Combined use of statins with antiretroviral drugs may lead to clinically relevant drug-drug interactions including reduced lipid lowering effects due to enhanced metabolism of statins and increased risk of potentially fatal rhabdomyolysis [28]. Some older anti-retroviral drugs like stavudine could be substituted with more lipid friendly drugs of the same class though mere switching to another regime may not alone produce the desired response. Nutritional supplementation of omega fatty acids may also help.

Switching of antiretroviral therapy is generally not indicated in HIV patients only for MeTS as the sole indication. Patients initiated on protease inhibitor based regime with complications of MeTS can be switched over to NNRTI based regimes if no contraindication exists. Alternatively, older PIs like Nelfinavir can be substituted with newer Pls like Atazanavir though the existing cosmetic changes are unlikely to reversed.

\section{Conclusion}

As HIV patients live longer, health care workers are more likely to treat patients with components of metabolic syndrome. However, the presentation of MeTS in HIV patients may not be the same as general population. With better understanding about the pathophysiology of chronic inflammation and endothelial dysfunction in HIV infection, it may become possible to initiate measures that can target the inflammatory pathways active in HIV infection. Future ART drugs may be developed with lesser impact on insulin resistance and lipid metabolism. As of now, the knowledge regarding this aspect of HIV infection is still in the early stages. 


\section{References}

1 Reaven GM (1988) Role of insulin resistance in human disease. Diabetes 37: 1595-1607.

2 Jaspinder Kaur (2014) A Comprehensive Review on Metabolic Syndrome. Cardiology Research and Practice pp: 1-21.

3 Alberti KG, Eckel RH, Grundy SM (2009) Harmonizing the metabolic syndrome: a joint interim statement of the international diabetes federation task force on epidemiology and prevention; National heart, lung, and blood institute; American heart association; World heart federation; International atherosclerosis society; And international association for the study of obesity. Circulation 120 : 1640-1645.

4 Alberti KG, Zimmet PZ (1998) Definition, diagnosis and classification of diabetes mellitus and its complications. Part 1: diagnosis and classification of diabetes mellitus provisional report of a WHO consultation. Diabetic Medicine 15: 539-553.

5 Balkau B, Charles MA (1999) Comment on the provisional report from the WHO consultation: European Group for the Study of Insulin Resistance (EGIR). Diabetic Medicine 16: 442-443.

6 Cleeman JI (2001) Executive summary of the third report of the National Cholesterol Education Program (NCEP) expert panel on detection, evaluation, and treatment of high blood cholesterol in adults (adult treatment panel III). Journal of the American Medical Association 285: 2486-2497.

7 Einhorn D, Reaven GM, Cobin RH (2003) American College of Endocrinology position statement on the insulin resistance syndrome. Endocrine Practice 9: 237-252.

8 http://www.idf.org/metabolic-syndrome

9 Aguilar M, Bhuket T, Torres S, Liu B (2015) Prevalence of the Metabolic Syndrome in the United States 2003-2012. JAMA 313: 1973-1974.

10 Pandit K, Goswami S, Ghosh S, Mukhopadhyay P, Chowdhury S (2012) Metabolic syndrome in South Asians. Indian Journal of Endocrinology and Metabolism 16: 44-55.

11 Lau DCW, Dhillon B, Yan H, Szmitko PE, Verma S (2005) Adipokines: molecular links between obesity and atherosclerosis. The American Journal of Physiology-Heart and Circulatory Physiology 288: H2031-H2041.

12 Roed T, Andreas Knudsen A, and Weis N (2014) Increased prevalence of coronary artery disease risk markers in patients with chronic hepatitis C - a cross-sectional study. Vasc Health Risk Manag 10: 55-62.

13 Amirzadegan A, Boroumand MA, Dehkordi MR, Goodarzynejad H (2007) Association between hepatitis B surface antibody seropositivity and coronary artery disease. Indian Journal of Medical Sciences 61: 648-655.
14 Paula AA, Falcao MCN, Pacheco AG (2013) Metabolic syndrome in HIV infected individuals: underlying mechanisms and epidemiological aspects. AIDS research and therapy 10: 32 .

15 Bastard JP, Maachi M, Lagathu C, Kim MJ, Caron M, et al. (2006) Recent advances in the relationship between obesity, inflammation, and insulin resistance. Eur Cytokine Netw 17: 4-12.

16 Kalantari P, Harandi OF, Hankey PA, Henderson AJ (2008) HIV-1 Tat mediates degradation of RON receptor tyrosine kinase, a regulator of inflammation. J Immunol 181: 1548-1555.

17 Neuhaus J, Jacobs DR, Baker JV, Calmy A, Duprez D, et al. (2010) Markers of inflammation, coagulation, and renal function are elevated in adults with HIV infection. J Infect Dis 201: 1788-1795.

18 Grunfeld C, Pang M, Doerrler W (1992) Lipids, lipoproteins, triglyceride clearance, and cytokines in human immunodeficiency virus infection and the acquired immunodeficiency syndrome. J Clin Endocrinol Metab 74: 1045-1052.

19 Lee GA, Seneviratne T, Noor MA (2004) The metabolic effects of lopinavir/ritonavir in HIV-negative men. AIDS 18: 641-649.

20 Murata H, Hruz PW, Mueckler M (2000) The mechanism of insulin resistance caused by hiv protease inhibitor therapy. J Biol Chem 275: 20251-20254.

21 Calcagno A, Ascenzo F (2005) Cardiovascular disease in HIV patients: from bench to bedside and backwards. Open Heart 20: 1-2.

22 Takara L, Steven K (2012) GrinspoonBody Composition and Metabolic Changes in HIV-Infected Patients. J Infect Dis 205: S383-S390.

23 Bergersen BM, Sandvik L, Dunlop O (2003) Prevalence of hypertension in HIV-positive patients on Highly Active Retroviral Therapy (HAART) compared with HAART-naive and HIV-negative controls: results from a Norwegian study of 721 patients. Eur J Clin Microbiol Infect Dis 22: 731-736.

24 Peck RN, Shedafa R, Kalluvya S (2014) Hypertension, kidney disease, HIV and antiretroviral therapy among Tanzanian adults: a crosssectional study. BMC Medicine 12: 125

25 Friis Moller N, Sabin CA, Webe R (2003) Combination antiretroviral therapy and the risk of myocardial infarction. The New England Journal of Medicine 349: 1993-2003.

26 Thoni GJ, Fedou C, Brun FJ (2002) Reduction of fat accumulation and lipid disorders by individualized light aerobic training in human immunodeficiency virus infected patients with lipodystrophy and/or dyslipidemia. Diabetes and Metabolism 28: 397-404.

27 Lazzaretti R, Kelbert S, Pinto J, Sprinz E (2006) Nutritional intervention protects against the development of dyslipidemia in patients who start HAART: a randomized trial, in Proceedings of the XIV International AIDS Conference,Toronto, Canada.

28 Burger D, Stroes E, Reiss P (2008) Drug interactions between statins and antiretroviral agents. Curr Opin HIV AIDS 3: 247-251. 